\author{
Agnati, Luigi Francesco, ${ }^{1}$ G. S. Minazheva, ${ }^{2}$ (D) M.S. Sadyrova, ${ }^{3}$ (D) N.V. Shakhmatova ${ }^{4}$ \\ ${ }^{1}$ Karolina Institute, Stockholm, Sweden \\ ${ }^{2}$ Al-Farabi Kazakh National University, Almaty, Kazakhstan \\ ${ }^{3}$ Saratov State University named after N.G. Chernyshevsky, Saratov, Russia \\ Gulsharat.Mynazheva@kaznu.kz
}

\title{
EMPLOYMENT OF GRADUATES OF KAZAKHSTAN UNIVERSITIES: ANALYSIS OF PROBLEMS
}

\begin{abstract}
The article is devoted to the analysis of the employment of graduates of Kazakhstan universities and the identification of existing problems. The purpose of this article is to provide an overview of some dominant empirical and conceptual topics in the field of employment of graduates of Kazakhstan universities. Global trends in higher education, the transition to a European educational model are making changes in the employment system of graduates of Kazakhstan's universities. The article identifies the main contradictions in the employment of graduates, on the basis of a sociological study among graduates the main factors are shown that contribute to solving the problem of effective employment of graduates. In this regard, it is considered advisable to implement the concept of interaction between the educational system and the labor market, which would ensure the saturation of the economy with qualified personnel.

The traditional human and cultural capital that employers have always demanded is currently only part of the narrative of graduate employment. The employment opportunity of graduates should increasingly be embodied in their so-called personal capital, which entails the integration of academic abilities with personal, interpersonal and behavioral qualities.
\end{abstract}

Keywords: graduate employment, competencies and skills of graduates, the effectiveness of graduates employment

Introduction.In modern conditions, the problem of employment of graduates great attention is given. It would be advisable to use the graduate employment rate as one of the many criteria for evaluating the effectiveness of universities. The employment of graduates is also associated with many objective factors that universities separately cannot influence (Talanov, 2014).

According to forecasts of the international investment firm Meryl Lang, Pira, Fenner and Smith, the demand for higher education on the planet in 2025 can reach 160 million study places (Selezneva, 2004). The global movement towards mass higher education raises even greater concerns regarding the distribution and fairness of the economic opportunities of graduates, as well as the traditional role of higher education authority in facilitating access to desired forms of employment.

In their studies, policymakers continue to emphasize the importance of "employment skills" so that graduates are fully prepared to solve problems in an increasingly flexible labor market (DIUS, 2008).

Monitoring the employment of university graduates is always relevant due to the increase in the share of employment of graduates and the low quality of training, that is, the disparity of graduates' competencies with the requirements of the employer (Gurtov, 2014):

Currently, existing mechanisms for employing graduates have been destroyed, ties between higher education institutions and production have been broken, and social order mechanisms for professions that are most in demand have not been developed (Yastrebov, 2012). In this regard, it is 
considered advisable to implement the concept of interaction between the educational system and the labor market, which would ensure the saturation of the economy with qualified personnel.

Literature review. The study by $M$. Tomlinson (2012) aims to set the problem of employment of graduates in the context of the changing relationship between higher education and the labor market, as well as the changing regulation of employment of graduates. M.Tomlinson is confident that graduates understand and try to manage their future "employment opportunity". According to M. Tomlinson, the dominant discourses on graduate employment opportunities, as a rule, focused on the economic role of graduates and the ability of higher education to prepare them for the labor market. Higher education systems around the world are developing in conjunction with wider structural transformations in developed post-industrial capitalism (Brown, 2009). Accordingly, graduates are perceived as potential key players in the desire to improve value-added products and services in an economy that requires stronger skills and advanced technical knowledge.

As noted in (DFE, 2010), state commitment to state financing of higher education has declined in recent years, but the state continues to put pressure on the system to increase its productivity, quality and overall market responsiveness. Such changes are associated with a shift towards a more flexible, post-industrial knowledge-based economy, which places increased demands on the workforce and requires new forms of professional skills (Hassard, 2008).

Relations between higher education and the labor market have traditionally been close to this, although sometimes they have been unstable and intangible (Brennan, 1996). He has traditionally helped regulate the flow of skilled, professional, and managerial workers. Thus, higher education has traditionally been seen as providing a positive platform through which graduates can successfully integrate into economic life and also effectively serve the economy (Johnston, 2003).

The expansion of higher education, as well as the creation of new forms of universities and the provision of various academic degrees have led university students to graduate from universities more heterogeneous (Scott, 2005).

Universities are increasingly joining a range of internal and external market forces, and their activities are increasingly adapting to the requirements of both employers and the new student "consumer" (Naidoo, 2005). The various stakeholders of higher education demand clear and tangible results in response to rising economic rates. The changing dynamics of the economics of higher education raises a number of important issues, not least related to equity and access to the labor market (Ainley, 1994).

Over the past decade, special attention has been paid to "employment skills," and the rationale is that universities equip students with the skills required by employers. There have been several concerted attacks by industry on skills mismatches between graduates and those required by employers (Archer, 2008).

There is also an opinion that the skills training program is somewhat symbolic and the "skills" embedded in the formal curricula of higher education are a poor attitude towards real and embodied beliefs (Ainley, 1994). A broader criticism of skills policies (Wolf, 2007) tends to cast doubt on the naive conceptualization of "skills", questioning both their actual relationship to employee practices and the extent to which they can truly be "demand oriented".

According to Clarke (Clarke, 2008), the discourse on job opportunities reflects the growing responsibility of individuals to constantly build their knowledge and skills. In fact, people can no longer rely on their existing education and labor market profiles to shape their longer-term career growth.

The increasingly flexible and skillful nature of modern employment means that highly educated people are gaining strength in the economy (Leadbetter, 2000), which requires the creative abilities and abstract knowledge of those who have completed higher education. They will be more productive, have a higher earning potential and be able to access better working conditions, have a higher status. 
On the other hand, less optimistic prospects tend to portray modern employment as more intense and unstable (Sennett, 2006). Relatively stable and consistent narrative descriptions of employment have given way to more fragmented and vague employment futures (Strangleman, 2007). In this situation, graduates will have to enter into an increasingly uncertain future of employment, constantly responding to the changing demands of internal and external labor markets. It can also lead to adverse experiences in the labor market, such as unemployment and underemployment. According to Brown \& etc (Brown, 2011), there is growing evidence that the principles of scientific management of the old style are adapting to the new digital era in the form of "digital Taylorism". And structural inequality can manifest itself in competition between different groups of graduates competing for highly demanded forms of employment.

Graduates see a connection between participation in higher education and future returns, which were disrupted as a result of mass higher education. This tends to be reflected in the perception among graduates that, although graduation makes it easier to access the desired job, it also increasingly plays a limited role (Tomlinson, 2007). These problems can further affect students' approaches to higher education in general, which are increasingly characterized by more instrumental, consumer-oriented, and acquisition-based learning approaches (Naidoo, 2005).

The degree of employment of a graduate varies over time, and the timing should be fixed so that results can be compared in space and time and by category (Istat, 2009). The effectiveness of education can also be seen as a long-term concept. It can be assessed several years after graduation, although over time, the consequences of inherited skills and those arising from society may be superior to those acquired at the university (Dey, 1999).

Graduates are more likely to see that the responsibility for future employment lies with the graduate himself: being a graduate and having graduate level diplomas, access to sought-after work is no longer guaranteed. Brooks and Everett (2008) have shown that while graduate-level education can be seen by graduates as preparation for lifelong learning and providing them with the inclination and confidence to further develop learning opportunities, many still consider the need for further vocational training and development far after graduation.

Ideally, graduates should have both hard currencies in the form of traditional academic qualifications and soft currencies in the form of cultural and interpersonal qualities (Tomlinson, 2012). The traditional human and cultural capital that employers have always demanded is currently only part of the narrative of graduate employment. The employment opportunity of graduates should increasingly be embodied in their so-called personal capital, which entails the integration of academic abilities with personal, interpersonal and behavioral qualities.

Well-designed and well-executed employment conditions may not necessarily coincide with the actual experience of graduates in the labor market and its results. This also applies to subject areas where there is traditionally a closer relationship between curriculum content and specific areas of work (Wilton, 2008).

Employers' penchant for recruiting specific "types" of graduates may reflect deeply rooted issues arising from more transactional, costly, and short-term approaches to human resource development (Warhurts, 2008). Thus, the successful integration of graduates in the labor market may be less dependent on the skills that they possess before it enters, and to a greater extent on the extent to which they are used and enriched due to their actual participation in the working environment.

Material and methods. Our study is quantitative, uses a student survey and analyzes a questionnaire to determine feedback from the main consumer-client of the educational process. During the questionnaire, we covered various stages and training courses, we believe that such a survey provides a deeper understanding of the issue under study. In order to guarantee the maximum level of confidentiality of responses, the questionnaire was conducted online.

Our article is based on existing literature and on the practical experience of the structural units of the university, as well as on the results of ratings and questionnaires. 
Respondents and procedure. In our study, we examine how the opinions of direct consumers are determined through feedback, and how competitive advantages are determined on the basis of the ratings carried out using benchmarking and SWOT analysis.

In the 2019-2020 academic year, an in-depth survey was conducted with university students, 262 respondents participated in the survey. Of these, 205 are female and 57 are male, studying under the grant - 191, in the paid department - 71, graduated from the city school - 202, and the rural school - 60 .

Measurement. Feedback from customer-clients was measured by questionnaires, specifying their level of satisfaction. To find out whether the departments establish feedback with the main customers-clients were asked questions such as "What specific procedures are used for feedback?", the questionnaire also asked the following questions: "What are your motives for choosing your specialty?", "Does it satisfy you the quality of education in high school? " etc.

Control variables include gender, specialty, etc. To solve the ethical problem when conducting research among students, the questionnaire was strictly voluntary and confidential, it was carried out jointly with the staff of the Career and Professional Development Center (CPDC) of KazNU.

Results and its discussion. The study was initiated in order to understand the relationship between the motivational structure of career choice and graduate employment. And also to identify factors affecting effective employment and identify negative factors of non-use of professional potential by graduates.

The graduate employment rate is one of the criteria for evaluating the work of universities in the world. The most effective, according to the Global Employability University Ranking-2015 (Global Employability University Ranking-2015), were Harvard University (USA), Cambridge and Oxford (United Kingdom). Universities in the USA and Great Britain accounted for most of the top 50 universities in this ranking.

The level of youth unemployment in Kazakhstan during the period from 2000 to 2014 decreased by 3.5 times (IAC, 2016). Despite the fact that the youth unemployment rate in Kazakhstan is much lower compared to the countries included in the first 55 countries - the competitiveness rating (The Global Competitiveness Index) - Switzerland (6.4\%), Singapore (6.7\%), Finland ( 22.7\%), Great Britain (13.8\%), Russia (18.8\%), Turkey (18.3\%). According to the Atameken NPP, the overall employment rate in Kazakhstan is $66 \%$ (with a coverage of 187,585 graduates), i.e. two thirds of graduates are employed. It cannot be said that the remaining $34 \%$ are unemployed, since these graduates can continue their studies in the country or abroad, find work abroad, find employment in the informal sector, join the army, and not enter the labor market for various reasons (illness, childbirth and care child and others). The stability (duration) of employment is $44 \%$, i.e. less than half. This means that out of, conditionally, two years from the moment of employment ( 24 months), the graduate actually works for 10.5 months, and the total breaks (one or several) in work are 13.5 months.

Higher education in itself does not guarantee successful employment. The results of the study show that a large number of respondents $(78.0 \%)$ consider having a diploma of higher education, is a guarantee of employment. $22.0 \%$ are committed to the fact that a higher education diploma is not enough in the modern labor market. There is an opinion in society that the higher education system is poorly oriented to the "real needs" of the economy. This, to a greater extent, relates to the number of students enrolled in universities on state orders.

The next group of respondents is of the opinion that personal skills are of great importance in employment. $66.0 \%$ of respondents are oriented to improve professional skills, that is, practical oriented. But, $19.0 \%$ of respondents doubt this, and $6.0 \%$ do not agree with this conclusion. This analysis shows the need for vocational training to pay more attention to practical exercises, industrial practices and laboratory exercises.

One of the factors affecting the employment of graduates is the motivation for employment after graduation. Analysis of the study revealed three areas of motivation for graduates. 
The first direction is orientation on employment by profession (29.0\%), not by profession (18.0\%), to open a business (13.0\%). It is alarming that only a small part of graduates are oriented to work in their specialty. This indicator shows the ineffective use of the professional potential of graduates, that is, more than $30.0 \%$ of graduates do not work in their specialty. In the study above, this question is combined with the control question "Where would you like to work after graduation?" $60.0 \%$ of respondents expressed a desire to work in their specialty, and $14.0 \%$ not in their specialty.

The second direction is orientation toward obtaining a second higher education (15.0\%), continuing professional education abroad (15.0\%), obtaining postgraduate education $(7.0 \%)$, the desire to do research $(3.0 \%)$. About $40.0 \%$ of respondents are motivated to further improve vocational education. It should be noted a low level of aspiration in obtaining postgraduate education. This shows a low level of motivation to engage in research work.

Most respondents $(60.0 \%)$ are confident that they will be employed. The results of this question correlate with the question related to the motives for choosing a profession. $62.0 \%$ of respondents in the structure of motives highlighted the desire to get a diploma of this university, and $28.0 \%$ noted a motive to get a profession. Indeed, the desire to become a specialist in a particular field is reflected in the effective employment of the graduate. The results of choosing a profession are less related to the influence of parents, competitiveness, and grants. That is, young people change their strategy when choosing a profession.

The difference between modern students is also the desire to continue professional education abroad (35.5\%), to obtain a diploma from another university (35.5\%), to open their own business $(30.0 \%)$. The data show that graduates are oriented to the modern requirements of employers and strive to be competitive in the labor market. Consequently, the employment of graduates depends on their attitude to the future profession, on expectations and motivational structure, professional skills. The study examined factors that positively and negatively affect the employment of graduates.

One of the problems is underemployment, that is, part-time employment of graduates. Respondents noted the importance of the graduate distribution system and agreements with enterprises and organizations.

An important factor is the attitude and requirements of employers to graduates. A sociological survey showed that $70 \%$ of employers are not satisfied with the professional skills of graduates. Modern employers are not only focused on having a diploma, they need highly educated, competent, communicative specialists. That is, they pay attention to the physical, professional, psychological, personal potential of the graduate. At the same time, the monitoring of the employment of college and university graduates is based on statistical data and does not provide feedback from graduates.

One of the factors is the level of confidence in employment. According to the results of the study, respondents rely mainly on themselves when searching for a job (90.4\%). Also, $26.3 \%$ of respondents trust the media, the Internet. The results also show the need to enhance the role of job fairs, employment services.

Respondents also noted difficulties in finding work in their specialty $(69.5 \%)$. This factor does not affect employment by profession. Also, respondents noted the following difficulties in finding employment such as lack of experience (43.0\%), corruption (41.2\%), theoretical nature of knowledge (39.0\%), inability to present oneself (36.2\%), ignorance of the labor market $(26.0 \%)$, legal incompetence $(14.0 \%)$.

The theoretical orientation of studying at the university also creates certain difficulties in the employment of graduates (IAC, 2016). The possibility of "accumulating" experience and further employment at the place of practical training could significantly reduce the unemployment rate among university graduates. However, the attitude of students themselves to practice is often formal.

One of the effective measures for employing university graduates is career guidance. Since 2020 , in order to stimulate the enterprises involved in the training of personnel for dual training, the 
Ministry of Education and Science of the Republic of Kazakhstan plans to reimburse their expenses for the remuneration of the mentor, consumables in the framework of per capita financing at the expense of the state educational order.

According to Superjob, more than a third of economists "would never have chosen this profession if they had the opportunity to change everything"; environmentalists would also like to take this opportunity. Even among architects who are most satisfied with their field, approximately one in five is not too happy with their chosen profession. In the opinion of Alexander Shmelev, professor at Moscow State University, professional tests can help reduce the risk of choosing a "not your own" profession, allowing you to find out the type of thinking, mental characteristics, interests and inclinations, the level of erudition, visual abstract logic, attention and personality types.

Conclusion. We believe that our study will help to understand the factors affecting the employment of graduates of Kazakhstan universities in modern conditions.

Only active cooperation between universities and employers can significantly bring educational technologies closer to labor market requirements (Ilyasov, 2008). The development dynamics of modern society increasingly requires the transformation of the country's leading universities into centers for the integration of science, education, production and business.

Strengthening the interaction between universities and employers will increase the proportion of the number of employed graduates (Mironov, 2013).

Strengthening partnerships with employers allows universities to additionally attract the resources of enterprises and organizations (intellectual, material, financial, etc.)

\section{References}

Ainley, P. (1994), Degrees of Difference, London: Lawrence Washart; Brown, P. and Hesketh, A.J. (2004), The Mismangement of Talent: Employability and Jobs in the Knowledge-Based Economy, Oxford: Oxford University Press.

Ainley, P. (1994), Degrees of Difference, London: Lawrence Washart Ainley (1994).

Archer, W. and Davison, J. (2008), Graduate Employability: The View of Employers, London: Council for Industry and Higher Education.

Brennan, J., Kogan, M. and Teichler, U. (1996), Higher Education and Work, London: Jessica Kingsley.

Brooks, R. and Everett, G. (2008), 'The predominance of work-based training in young graduates' learning', Journal of Education and Work 21(1): 61-73) и Литтла (Little, В. (2008) 'Graduate development in European employment: Issues and contradictions', Education and Training 50(5): 379-390.

Brown, P. and Hesketh, A.J. (2004), The Mismangement of Talent: Employability and Jobs in the Knowledge-Based Economy, Oxford: Oxford University Press.

Brown, P. and Lauder, H. (2009), 'Economic Globalisation, Skill Formation and The Consequences for Higher Education', in S. Ball, M. Apple and L. Gandin (eds.) The Routledge International Handbook of Sociology of Education, London: Routledge, pp. 229-240.

Brown, P., Lauder, H. and Ashton, D.N. (2011), The Global Auction: The Broken Promises of Education, Jobs and Incomes, Oxford: Oxford University Press.

Clarke, M. (2008), 'Understanding and managing employability in changing career contexts', Journal of European Industrial Training 32(4): 258-284.

Department for Business Innovation and Skills (DIUS). (2008) Higher Education at Work High Skills: High Value, London: HMSO.

Department for Education (DFE). (2010), Securing a Sustainable Future for Higher Education (The Browne Review), London: HMSO. DFE, 2010.

Dey, E. L., Wimsatt, L. A., Rhee, B. S., \& Meader, E. W. (1999), Long-term effect of college quality on the occupational status of students. National Center for Postsecondary Improvement, Stanford University, Technical Report Number 5-06. 
Gurtov V.A. (2014), Development of a system for monitoring the employment of graduates / V. Gurtov, L. Serova, I. Stepus, E. Fedorova, D. Moroz. // Higher education in Russia. No. 5, p. 11-23 (p. 12) access mode: http://elibrary.ru/item.asp?id=21518997.

Ilyasov E. P. (2008), Interaction of universities and employers in the conditions of development of market relations in the economy and the problem of employment of graduates of vocational education institutions // Uchenye Zapiski Kazan University. Series: Humanities. Vol. 150, No. 4. S. 208-221.

Information and Analytical Center. http://iac.kz Employment of graduates of Kazakhstan universities. Alma mater. Bulletin of Higher School No. 3, March 2016.

Istat. (2009), I laureati e lo studio. Inserimento professionale dei laureati. Indagine 2007. Roma: Istat;

Fabbris, L. (2010), Il Progetto Agora dell'Universita di Padova. In Fabbris, L. (ed.), Dal Bo' all'Agorn, il capitale umano investito nel lavoro (pp. V-XLVI). Cleup, Padova;

Cammelli, A., \& Gasperoni, G. (2012), Higher education external effectiveness indicators with reference to Italian universities. In L. Fabbris (Ed.), Indicators of higher education effectiveness (pp. 171-182). Milan: McGraw-Hill Education;

Lucarelli, C., Ungaro, P., \& Verzicco, L. (2012), Employment rate as a measure of educational return. In L. Fabbris (Ed.), Indicators of higher education effectiveness (pp. 35-48). Milan: McGraw-Hill Education.

Hassard, J., McCann, L. and Morris, J.L. (2008), Managing in the New Economy: Restructuring White-Collar Work in the USA, UK and Japan, Cambridge: Cambridge University Press. Hassard et al., 2008. http://proforientation.ru/vybor-puti.html; http://www.superjob.ru/research/articles/111726/menshe-vsego-dovolnyh-vyborom-professii-srediekonomistov-tehnologov-i-ekologov/; https://atameken.kz/ru/university_ratings

Johnston, B. (2003), 'The shape of research in the field of higher education and graduate employment: Some issues', Studies in Higher Education 28(4): 413-426.

Leadbetter, C. (2000), Living on Thin Air, London: Penguin.

Michael Tomlinson (2012), Graduate Employability: A Review of Conceptual and Empirical Themes. Higher Education Policy 25, (407-431).

Michael Tomlinson (2012), Graduate Employability: A Review of Conceptual and Empirical Themes. Higher Education Policy 25, p. 420-421.

Mironov V.V., Ilyasov E.P., Gurtov V.A. (2013), On government measures to organize the interaction of educational organizations of vocational education and employers in order to successfully employ graduates // Higher Education in Russia.No. 11. S. 17-21.

Naidoo, R. and Jamieson, I. (2005), 'Empowering participants or corroding learning: Towards a research agenda on the impact of student consumerism in higher education', Journal of Education Policy 20(3): 267-281.;

Marginson, S. (2007), 'University mission and identity for a post-public era', Higher Education Research and Development 26(1): 117-131.

Naidoo, R. and Jamieson, I. (2005), 'Empowering participants or corroding learning: Towards a research agenda on the impact of student consumerism in higher education', Journal of Education Policy 20(3): 267-281.

Scott, P. (2005), 'Universities and the knowledge economy', Minerva 43(3): 297-309.

Scott, P. (2005), 'Universities and the knowledge economy', Minerva 43(3): 297-309.

Sennett, R. (2006), The Culture of New Capitalism, Yale: Yale University Press.

Strangleman, T. (2007), 'The nostalgia for the permanence of work? The end of work and its commentators', The Sociological Review 55(1): 81-103.

Selezneva N.A. (2004), Reflections on the quality of education: an international aspect // Higher education today. - M . - No. 4. - S. 35-44. 
State program for the development of education and science of the Republic of Kazakhstan for 2020 - 2025. Approved by the Decree of the Government of the Republic of Kazakhstan dated December 27, 2019 No. 988.

Talanov S.L. (2014), Employment of university graduates as a criterion for assessing the effectiveness of their activities // Alma mater. No. 3 (March). -S. 35-39.

Tomlinson, M. (2007), 'Graduate employability and student attitudes and orientations to the labour market', Journal of Education and Work 20(4): 285-304;

Brooks, R. and Everett, G. (2009), 'Post-graduate reflections on the value of a degree', British Educational Research Journal 35(3): 333-349;

Little, B. and Archer, L. (2010), 'Less time to study, less well prepared for work, yet satisfied with higher education: A UK perspective on links between higher education and the labour market', Journal of Education and Work 23(3): 275-296.

Warhurst, C. (2008), 'The knowledge economy, skills and government labour market intervention',Policy Studies 29(1): 71-86.

Wilton, N. (2008), 'Business graduates and management jobs: An employability match made in heaven?' Journal of Education and Work 21(2): 143-158;

Rae, D. (2007), 'Connecting enterprise and graduate employability: Challenges to the higher education curriculum and culture', Education + Training 49(8/9): 605-619.

Wolf, A. (2007), 'Round and round the houses: The Leitch review of skills', Local Economy 22(2): 111-117. Wolf, 2007.

Yastrebov A.P., Moiseuk V.G. (2012), The demand for graduates as an indicator of the quality of educational activities of the university // Economics and Management. No. 4 (78), p. 83-86.

\author{
Антони, Луичжи Франческо, ${ }^{1}$ Г. С. Минажева, ${ }^{2}$ М.С. Садырова,${ }^{3}$ Н.В. Шахматова ${ }^{4}$ \\ ${ }^{1}$ Каралинский институт, Стокгольм, Швеция \\ 1Әл-Фараби атындағы ҚазҰУ, Алматы, Қазақстан, \\ ${ }^{2}$ Н.Г. Чернышевский атындағы Саратов мемлекеттік университеті, Саратов қ., Ресей
}

\title{
ҚАЗАҚСТАНДЫҚ ЖОҒАРЫ ОКУ ОРЫНДАРЫНЫН ТУЛЕКТЕРІН ЖҰМЫСҚА ОРНАЛАСТЫРУ: ПРОБЛЕМАЛАРДЫ ТАЛДАУ
}

Андатпа. Мақала қазақстандық жоғары оқу орындарының түлектерін жұмысқа орналастыруды талдауға және орын алған проблемаларды анықтауға арналған. Мақаланың мақсаты - қазақстандық жоғары оқу орындарының түлектерін жұмысқа орналастыру саласындағы эмпирикалық және концептуалды тақырыптарға шолу жасау. Жоғары білім берудегі әлемдік тенденциялар, еуропалық білім беру моделіне көшу қазақстандық ЖОО түлектерінің жұмысқа орналасу жүйесіне өзгеріс енгізуде. Мақалада түлектерді жұмысқа орналастырудағы негізгі қайшылықтар анықталған, түлектер арасындағы әлеуметтік зерттеу негізінде түлектерді тиімді жұмыспен қамту мәселесін шешуге ықпал ететін негізгі факторлар көрсетілген. Осыған байланысты экономиканың білікті кадрлармен қанығуын қамтамасыз ететін білім беру жүйесі мен еңбек нарығы арасындағы өзара іс-қимыл тұжырымдамасын жүзеге асыру орынды деп саналады.

Жұмыс берушілер әрдайым сұраған дәстүрлі адами және мәдени капитал қазіргі уақытта түлектерді жұмысқа орналастыру туралы баяндаудың бір бөлігі ғана. Түлектердің жұмысқа орналасу мүмкіндігі олардың жеке капиталы деп қарастырылуы керек, бұл академиялық қабілеттердің тұлғалық, тұлғааралық және мінез-құлық қасиеттерімен интеграциялануын қажет етеді.

Түйін сөздер: түлектердің жұмысқа орналасу мүмкіндігі, түлектердің біліктілігі мен дағдылары, түлектердің жұмысқа орналасу тиімділігі 
Антони, Луичжи Франческо ${ }^{1}$, Г.С. Минажева, ${ }^{2}$ М.С. Садырова, ${ }^{3}$ Н.В. Шахматова ${ }^{4}$

${ }^{1}$ Каралинский институт, Стокгольм, Швеция

${ }^{2}$ Казахский национальный университет имени аль-Фараби, г. Алматы, Казахстан

${ }^{3}$ Саратовский государственный университет им. Н.Г. Чернышевского, г. Саратов, Россия

\title{
ТРУДОУСТРОЙСТВО ВЫПУСКНИКОВ КАЗАХСТАНСКИХ ВЫСШИХ УЧЕБНЫХ ЗАВЕДЕНИЙ: АНАЛИЗ ПРОБЛЕМ
}

\begin{abstract}
Аннотация. Статья посвящена анализу трудоустройства выпускников казахстанских вузов и выявлению существующих проблем. Целью данной статьи является предоставление обзора некоторых доминирующих эмпирических и концептуальных тем в области трудоустройства выпускников казахстанских вузов. Мировые тенденции в сфере высшего образования, переход к европейской образовательной модели вносят изменения в системе занятости выпускников вузов РК. В статье выявлены основные противоречия в трудоустройстве выпускников, на основе проведенного социологического исследования среди выпускников показаны основные факторы, способствующие решению проблемы эффективного трудоустройства выпускников. В этой связи считается целесообразной реализация концепции взаимодействия образовательной системы и рынка труда, которая обеспечила бы насыщение экономики квалифицированными кадрами.

Традиционный человеческий и культурный капитал, которого работодатели всегда требовали, в настоящее время является лишь частью повествования о трудоустройстве выпускников. Возможность трудоустройства выпускников все чаще должна воплощаться в их так называемый личный капитал, что влечет за собой интеграцию академических способностей с личными, межличностными и поведенческими качествами.

Ключевые слова: трудоустройство выпускников, компетенций и навыки выпускников, эффективность трудоустройства выпускников
\end{abstract}

